\title{
ANTHROPOLOGY AND SOCIOLOGY IN TOURISM DOCTORAL RESEARCH
}

\begin{abstract}
:
Tourism doctoral dissertations have grown exponentially in recent years. Despite this, there have been limited studies which examine the contribution of specific disciplines to tourism doctoral research over time. Subsequently, this manuscript explores the theories, concepts and methods employed in tourism doctoral dissertations informed by the foundation disciplines of anthropology and sociology. Drawing on a database of 2,155 dissertations from four countries, findings revealed exponential growth in doctoral theses grounded in anthropology and sociology between 1969 and 2013. The USA is the primary location for tourism doctoral theses informed by anthropology and sociology, with the University of California the leading institution. Analysis revealed identity theory was the predominant theory, with socio-cultural change, ethnicity and culture core concepts. Results also showed an increase in qualitative and mixed methods research. Future research should examine tourism doctoral theses housed in other disciplines, drawing inferences for future scholarly inquiry.
\end{abstract}

Key Words: Anthropology; Sociology; Tourism; Doctoral Research; Dissertations

\section{INTRODUCTION}

Tourism is one of the world's major industries, accounting for widespread economic benefits to destination regions (Webster and Ivanov, 2014). According to Jafari (2003) the economic aspects of tourism (e.g. employment, economic activities, per capita expenditure and multiplier effects) were the first to be explored by researchers in the 1960s forming the so called "advocacy platform". Although the influence of economics on tourism research was widespread in the early years, today it has experienced a considerable decline in favour of other disciplines such as psychology, environmental studies, anthropology and sociology, including in postdoctoral research (Weiler, Moyle and McLennan, 2012).

With the growth of the tourism and hospitality education sector, doctoral research focused on tourism has grown exponentially (Afifi, 2009, 2013; Botterill, Haven and Gale, 2002; Carr and Hayes, 2016; Hall, 1991; Huang, 2011; Jafari and Aaser, 1988; Laing and Weiler, 2008; Meyer-Arendt and Justice, 2002; Tonghui, Caihua, Wei, Qinjian and Zhiping, 2016; Weiler et al., 2012). Weiler et al. (2012: 1426) argue that judging a field of research from the quantity of input (e.g. number of programs, 
researchers, research funding) or output (e.g. number of journal papers, graduates, dissertations) can present an "incomplete" and "superficial perspective". Insight into the growth and theoretical maturity of an applied field such as tourism can be enhanced by analysing the extent to which research is informed by foundation disciplines, including how it reflects inter- or multidisciplinarity or the borrowing and melding of theories, philosophies and techniques from two or more disciplinary backgrounds (Tribe and Liburd, 2016; Leiper, 1981; Weiler et al., 2012).

Treating tourism as an applied and interdisciplinary field of research rather than a discipline in its own right has resulted in the various disciplines that inform doctoral-level research becoming the subject of intense scholarly inquiry (Afifi, 2009; Jafari, 2003; Jafari and Aaser, 1988; Weiler et al., 2012). Consequently, this paper aims to explore how the disciplines of anthropology and sociology have contributed to theoretical and methodological developments in tourism doctoral research. Although anthropology and sociology have much in common and share important aspects of theory and method, they have distinct disciplinary traditions. The former (anthropology) is more concerned with human culture and social diversity explored through long term ethnographic fieldwork, whereas the latter (sociology) with society, social behaviour, practices and institutions.

Each of these disciplines have over the years evolved from the theoretical and methodological contributions of their respective founding fathers. In anthropology core scholars include Boas, Malinowski, Radcliff-Brown and Mauss, with Kant, Durkheim, Marx, Comte and Weber driving key theoretical advancements in sociology and the broader social sciences. Each discipline has sought to connect to 21 st century concerns such as globalisation, mobility and the representation of people and culture in an interconnected world (Marcus and Fisher, 1986; Urry, 2000). Scholarship published in the respective leading disciplinary journals - Annual Review of Anthropology, Current Anthropology, American Journal of Sociology and Annual Review of Sociology - provides more in-depth information on the dominant concerns in the respective disciplines of anthropology and sociology which is beyond the scope of the current manuscript.

Dann (2005) argues that researchers from the fields of anthropology and sociology are among the major contributors to scholarly developments in tourism studies. Since theoretical developments in anthropology and sociology have followed similar historical evolutions, their respective contribution to tourism research is not easily distinguishable (Dann, 2005; Nash, 2007; Nash and Smith, 1991). Indeed, the contribution of these two disciplines to tourism theory has often been an "amalgam" as anthropological vs sociological "disciplinary provenance has typically been blurred" (Dann, 2005: 4). Similarly, in the prologue to the edited volume The Study of Tourism: Anthropological and Sociological Beginnings, Nash (2007) justifies the decision to consider both anthropological and sociological approaches to tourism together by arguing that the two disciplines have had similar histories which overlap considerably and their contribution to tourism is almost a "fusion" of both 
perspectives. Likewise, Nash and Smith (1991: 22) argue that to distinguish between the contribution that anthropology has had to tourism research and the contribution from other social sciences is a complex endeavour as "the discipline's boundaries are not well developed where tourism is concerned, and it is indeed possible to see a good deal of overlap".

Based on these arguments, this paper seeks to examine the disciplines of anthropology and sociology as one subset of tourism doctoral dissertations completed in the United States, Canada, Australia and New Zealand. The paper unearths the contribution these two disciplines have made to tourism doctoral research, highlighting the concepts, theories and methods employed and trends over the years. Rather than identify the disciplinary context/provenance of the research (i.e. the school, department or administrative unit in which the research was completed), individual abstracts were analysed to identify the extent to which sociology and anthropology have informed doctoral research in tourism. Prior to research by Weiler et al. (2012), this approach has not been taken in tourism research and is more inclusive than limiting the study to only those dissertations completed in a department or school of anthropology or sociology. Determining disciplinary influence through content analysis also makes it possible to identify multiple disciplines within a single thesis. This approach is useful in assessing the interdisciplinary nature of research, particularly in applied fields, and thus has been previously used in nursing (Spear, 2011) and public administration research (Adams and White, 1994).

\section{TRACING THE THEORETICAL DEVELOPMENTS IN THE ANTHROPOLOGY AND SOCIOLOGY OF TOURISM}

In a review of the anthropological and sociological beginnings of tourism studies, Nash (2007) noted that it was not until the 1970s that the study of tourism emerged as a topic in the disciplines of sociology or anthropology. Delay in the study of tourism within the two disciplines has been attributed to a number of reasons (Crick, 1989; Scott and Selwyn, 2010), including perceptions about the relevance of tourism research to the social sciences being purely about economics (Burns, 2004). Scott and Selwyn (2010) argue that in the 1960s and 1970s most social scientists were content to ignore the presence of tourism and tourists when conducting fieldwork. They refer to the "black box" approach to tourism, which was seen as just another kind of industrial input.

Prior to the development of a recognisable anthropology or sociology of tourism, "elements that now form part of it were being explored by sociologists and anthropologists in a number of contexts" (Burns, 2004: 9). Seminal work on the sociology and anthropology of tourism was pioneered during the 1970s (Boissevain, 1977; Cohen, 1972, 1979; de Kadt, 1979; MacCannell, 1976; Smith, 1977a; Turner and Ash, 1975; Young, 1977), and inspired the inauguration of journals such as Annals of 
Tourism Research in 1973. Early theorising on tourism took two forms, the first sustained by Graburn (1977) and MacCannell (1976) which sought to understand the origins of tourism and its symbolic meanings, and the second put forward by Nash (1977) and Nuñez (1963) which focused on the social, political, economic and environmental effects of tourism development (Lett, 1989; Stronza, 2001). Dann (2005) argues, however, that theoretical contributions were only original in their application to the study of tourism, being well established in anthropology and sociology.

Building on van Gennep's (1960) idea of transition from one social category to another, for example, Turner (1969) proposed that travelling is a stage in an individual's life cycle, a "rite of passage" or a "ritual" comparable to a pilgrimage. Likewise, Graburn (1977) builds on Durkheim's notions of sacred and profane, introducing the concept of tourism as "sacred journey". This view of tourism as a symbolic means of expressing and maintaining human identity is also shared by MacCannell (1976) who argued tourism was a ritual of modern people in search for "authenticity"; a quality lacking in modern social life.

These early perspectives were based on a dialectic approach to tourism and modernity and dichotomies such as tourists or guests and residents or hosts (Meethan, 2001). On the one hand tourists wished to escape modernity in search of authenticity, and on the other hosts would stage such cultural performances for economic benefits (Cohen and Cohen, 2012). The preoccupation with the interaction between hosts and guests, and the subsequent cultural changes which took place in host communities, were first explored by Nuñez (1963) in his study on the impacts of tourism on a Mexican village in which he applied for the first time the acculturation model of contact to the study of tourism.

In a similar fashion, a number of anthropological accounts on the impacts of tourism on host communities revealed the growing preoccupation with the negative socio-cultural implications of tourism for host communities. Some of these accounts were collected in Smith's (1977b) seminal book Hosts and Guests: The Anthropology of Tourism which is now accepted as being the cornerstone of a recognisable "anthropology of tourism". Early sociologists' accounts and views of tourism were also pervaded by the "impact model" of tourism (Leite and Graburn, 2009) or, as MacCannell (cited in Burns, 2004, p. 9) calls it, a "pro-tourist" vs "anti-tourist" approach. From these early sociological and anthropological approaches to the study of tourism, labelled by Jafari (2003) as the "cautionary platform" and by Easterling (2004) as the "dark side" of tourism, social scientists focused on a more balanced view of tourism often recognising the "constructive aspect" of the changes brought about by tourism (Nash and Smith, 1991: 15).

In the 1980s, anthropologists and sociologists began to challenge the notion of tourism as an exogenous force impacting upon inert and passive host communities (Crick, 1989; Picard, 1995). A small group of anthropologists and sociologists, that by the mid-1980s had developed into an 
international network and permanent research committee of the International Sociological Association (ISA), started to explore international tourism as an agent of social change and a catalyst for the transformation of identities and cultures (Lanfant, Allcock and Bruner, 1995). By linking identity, change and international tourism, these social scientists sought to advance tourism as a legitimate field of enquiry. The collection of studies in the edited book International Tourism: Identity and Change mirror the wave of political and Marxist critiques which were taking place within the disciplines of anthropology and sociology (Lanfant et al., 1995). For instance, there was a conscious realisation and intense scholarly discourse surrounding the issue that communities and societies are not immune to outside contact and historical processes of change (Canosa, 2014; Nash and Smith, 1991).

On that note, McGibbon (1999) argues that it was precisely the phenomenon of globalisation that led anthropologists and sociologists to reconsider some of the basic concepts of the disciplines such as "culture", "society", and "identity". According to Appadurai (1998), units of analysis such as "villages", "communities" and "localities" needed to be replaced by "ethnoscapes" or landscapes of group identity, a term which considered the global processes of movement and portrayed the fluidity and mobility of the world. During the 1990s, studies such as Picard's (1995) research on cultural tourism in Bali emerged. Picard rejected the view of international tourism as merely an external agent of change and put forward the argument that local communities respond to change and international tourism in a transformative way which he defined as a process, the touristification process.

These theoretical developments in the anthropological and sociological study of tourism follow the postmodern and poststructuralist turn of the late-20th century in the broader social sciences (Cohen and Cohen, 2012). The postmodern turn in Western tourism, as well as the rise of non-Western tourism, affected the modes of anthropological and sociological thinking about tourism, the paradigmatic and theoretical approaches to it, and the choice of research topics (Cohen and Cohen, 2012; Errington and Gewertz, 1989). Bruner (1991), for example, challenged the concept of authenticity arguing that the existence of a true original (an authentic) is essentially flawed; in reality there are no originals, only endless reproductions. Turning away from discourses of authenticity and cultural commodification, the anthropological and sociological study of tourism embraced the postmodern turn, increasingly denying the existence of "originals" and introducing the concept of "simulacra" (Baudrillard cited in Cohen and Cohen, 2012: 2179). According to these views, "posttourists" actually enjoy simulacra in a 'world supposedly devoid of originals' (Cohen and Cohen, 2012: 2179).

Another important theoretical contribution of the 1990s came from the sociologist Urry (1990) who proposed a sociology of tourism based on the examination of the changing forms of the "tourist gaze" as per Foucault's notion of historically specific ways of viewing the outside world (Kearney, 1995). 
More recently, Urry (2000: 13) also proposed a move away from the "ontology of distinct 'places' and "people" (Hannam, Sheller and Urry, 2006: 13) directing our attention to new researchable entities: "fluxes and flows", "place-making", and practices of seeing, imagining, and remembering (Büsher and Urry, 2009: 110). Globalisation has produced a noticeable shift in the social sciences, away from the traditional emphasis on places and identities as fixed in time and space towards a recognition of the fluidity and liquidity of the present world, "criss-crossed by a multitude of tourists, workers, terrorists, students and migrants" (Hannam et al., 2006: 2).

The "mobility turn" in tourism studies or "mobilities paradigm" is another important contribution of sociology and anthropology to the study of tourism and traces of its concepts can be seen right across the social sciences particularly in anthropology. The poststructuralist phase of the 1990s saw a rise in studies which depicted cultures and identities as highly contextual, dynamic and increasingly hybrid (Hall, 1996; Olwig, 1997; Schwartz, 1995; Poole, 1994). Identities, like society, came to be seen as fluid, no longer temporally and spatially static but in a continuous state of flux and renewal (Canosa, 2014; Rapport and Dawson, 1998).

The feminist turn in the social sciences also provided a radical departure from and critique of masculinist accounts and disembodied theoretical scholarship in the sociological/anthropological study of tourism (Johnston, 2001; Swain, 1995; Veijola and Jokinen 1994). As such, studies emerged which privileged voices that had until then remained silent in tourism social science including, for example, doctoral research on colonialism, violence, and patriarchy in backpacking practices in India (Lozanski, 2007).

These theoretical developments have had important implications for the fieldwork practices and methodological approaches traditionally employed in sociology and anthropology. An increase in "mobile ethnographies" (Büscher, and Urry, 2009) or "multi-sited" ethnographies (Kurotani, 2004; Marcus, 1995) started to emerge in the study of tourism. Ethnographies of diaspora and "roots" tourism, for example, employed the methodology of "following the tourist" focusing on the ritualised and embodied experience of tourism (Bruner, 1996; Cohen, 2008; Duval, 2003; Leite, 2005). Other studies followed objects (e.g. souvenirs, relics or photographs) and the "production, diffusion, consumption and re-representation" of tourist images and imaginaries (Di Giovine, 2011: n.p.). These studies have analysed how objects take on new meanings as they circulate contributing to the spread of imagery and representations about tourist destinations (Morgan and Pritchard, 2005).

The recounting of memories and travel experiences connected to images, souvenirs and relics also led to another important theoretical development in the sociology/anthropology of tourism. According to Salazar (2012: 864) the ensemble of socially transmitted representations of people's imaginings about the world are referred to as "imaginaries". Studies of the production and consumption of tourist imaginaries - and the role that memory plays in the construction of imaginaries of people and places - 
have been able to shed light on the peculiarities and intricacies of the meaning-making or worldmaking force of tourism (Adams, 2004; Gravari-Barbas and Graburn, 2012; Harrison, 2001; Hollinshead, 2009; Leite, 2005, 2014; Salazar, 2012).

With the realisation that single-sited ethnography was no longer adequate to capture the mobility of people and places and the interconnectedness of the world (Salazar, 2010), a proliferation of new methodological approaches blossomed in the sociology and anthropology of tourism. Virtual ethnography/ netnography, for example, allows exploration of social networks through the analysis of blogs, social media postings (such as on Facebook and Twitter), user-generated photos through Flickr and Instagram or user-generated tourism sites such as TripAdvisor (Di Giovine, 2011; Mkono, 2012). Visual, film and art-based methodologies are also on the rise in the sociological/anthropological study of tourism (see also Bandyopadhyay, 2011; Canosa, Wilson and Graham, 2017; Rakić and Chambers, 2010; Rydzik, Pritchard, Morgan and Sedgley, 2013; Scarles, 2010).

In summary, these theoretical and methodological developments in the study of tourism are a reflection of not only the postmodern and mobility turn in the disciplines of sociology and anthropology (Hannam et al., 2006; Büsher and Urry, 2009), but also the rise of actor-network theory (ANT) (Ren, 2010, 2011; Tribe, 2010); the performativity approach and embodiment (see also Edensor, 2001; Frohlick and Johnston, 2011; Harrison, 2001; Jordan and Aitchison, 2008; Sampaio, Simoni and Isnart, 2014; Simoni, 2014; Small, 2016); the politics of representation and circulation of imaginaries (Adams, 2004; Gravari-Barbas and Graburn, 2012; Hollinshead, 2009; Leite, 2005, 2014; Salazar, 2012); and identities and the construction of places and people (Canosa, Graham \& Wilson, 2017; Desforges, 2000; Duval, 2003; McCabe and Stokoe, 2004; Noy, 2004). In addition, the recent emergence of critical tourism studies has broadened the horizons to include many research interests which have a long history both in sociology and anthropology including: racial and ethnic minorities and indigenous studies; gendered and feminist approaches; emotion and embodiment; class, disability and age studies; peace, social justice and community development/empowerment; and participatory and co-created knowledge (Canosa, 2016; Pritchard, Morgan and Ateljevic, 2011; Stronza, 2001; Tribe, Xiao and Chambers, 2012).

With these recent advances in the sociology and anthropology of tourism, it is timely to consider the role of anthropology and sociology in tourism doctoral research. Arguably, dissertations, particularly $\mathrm{PhD}$ theses, are a barometer for theoretical, conceptual and methodological advancement within specific disciplines, in this instance, in the tourism field. As such the aim of the present paper is to explore the role of anthropology and sociology in tourism-focused dissertations, from 1969 to 2013. Specifically, this paper contributes to the literature by exploring the scholarly contributions of sociology and anthropology to the study of tourism by analysing doctoral-level research. The theories, 
concepts and methods uncovered in this literature review informed the coding of each dissertation, as discussed in the next section of the paper.

\section{METHODS}

This research uses a database of 2,155 tourism doctoral dissertations completed in the United States, Canada, Australia and New Zealand between 1951 and 2013 to explore the contribution of anthropology and sociology to tourism doctoral research. The decision to focus on dissertations completed in these four countries was made in order to create a comprehensive dataset for Englishspeaking countries in which doctoral research had not been recently reviewed. Readers interested in doctoral research output in the UK are encouraged to read Botterill, Haven and Gale (2002) and Afifi (2013).

This database was compiled by searching four online databases that catalogue and inventory doctoral research. Key words used to search the databases were identified from previous studies and included hotel, hospitality, leisure, tourism, tourist, travel, tour, recreation, holiday, vacation, guide, trip and heritage (Weiler et al., 2012). A total of approximately 20,000 dissertations were identified with this method, over 18,000 of which were excluded based on the information included in the abstract. It is important to note that any thesis that was not focused on tourism was excluded at this stage. For example, the search terms 'trip', 'travel', 'heritage' and 'guide' picked up literally thousands of theses that had nothing to do with tourism, given the multiple meanings and uses of these terms in the English language.

In total, 1,888 valid tourism-focused doctoral dissertations were coded into different disciplines based on previous studies (Jafari and Ritchie, 1981). The database was originally compiled at the end of 2009 , then updated to include theses to the end of 2013 using the same process, resulting in 2,155 theses for subsequent coding and analysis.

As previously discussed, rather than extract dissertations from this database based on the department or school in which the research was completed, each individual thesis (using title, keywords and abstract) was analysed to ascertain whether the thesis was informed by different disciplines, including sociology and/or anthropology. Using titles, abstracts and keywords to identify sociological and anthropological theory and concepts was considered a notable improvement over simply relying on the School or Department in which the thesis was undertaken, as has been done in previous research of this kind (Jafari and Aaser, 1988; Hall and Pedrazzini, 1989; Botterill, Haven and Gale, 2002; Meyer-Arendt and Justice, 2002). 
Weiler et al. (2012) argue that this is a more rigorous method of identifying disciplinary provenance or background as it accommodates disciplinary coding regardless of positioning in a particular university department, as well as allowing for coding to more than one discipline. Theses completed in business, tourism and hospitality schools, for example, are not overlooked by this approach. Once coded into disciplines, the theses which were identified as drawing on the disciplines of anthropology and sociology were then extracted from the database for subsequent further coding and analysis. While this method has captured far more theses than limiting the analysis to those completed in an Anthropology or Sociology School or Department, no doubt some tourism-focussed dissertations have been missed.

From 1969 to 2013 there have been 476 tourism-focused theses informed by anthropology and/or sociology, representing $22.5 \%$ of all theses in the database $(n=2,115)$. Of these, 292 drew on anthropology and 220 drew on sociology, with 36 of these drawing on both anthropology and sociology. The subset of theses was then inductively coded with regard to the categories of "concept", "theory" and "method" using the information contained in the abstract and informed by the concepts, theories and methods identified in the review of literature on the contribution of sociology and anthropology to the study of tourism (Burns, 2004; Cohen and Cohen, 2012; Dann, 2005; Graburn, 1983; Leite and Graburn, 2009; Leite and Swain, 2015; Nash, 2007). In instances where no appropriate category could be found the theses were coded using a grounded approach. To limit the number of possible categories some terms were aggregated. We acknowledge, however, that in some instances these terms are not interchangeable (e.g. 'sexuality' and 'romance' or 'development theory' and 'sustainable development theory').

An inter-coder reliability test was performed by having four independent researchers with a background in anthropology and/or sociology review the coding of every $20^{\text {th }}$ dissertation. This process resulted in an inter-coder reliability score of over $85 \%$ as recommended by Huberman and Miles (2002). In instances where inconsistencies in the coding was identified the four researchers had a discussion until consensus was reached.

The analysis sought to explore the number of doctoral theses informed by sociology and anthropology and how these compare across the four countries, the educational institutions at which the dissertations have been completed, connections to other disciplines, study locations, and the concepts, theories and methods prevalent in dissertations. The data were binary coded and analysed using descriptive statistics in STATA v.13. Chi-square and Fisher exact tests were used to determine significance. Both tests were employed simultaneously during cross-tabulation of the data in STATA. Chi-square tests were used when the requirement that at least five observations are contained within each cell of the table was satisfied. Fisher's exact test, which does not have this requirement, was used when observations in the table cells fell below the requirement for chi-square tests. 
Some other limitations associated with the approach taken for this research must be acknowledged. Firstly, abstracts varied in length and quality and this may have influenced the analysis. Some abstracts were, for example, very brief, making it difficult to code in all available categories (concepts, theories and methods). In instances where essential information related to theories, concepts and methods was missing from the abstract, the full dissertation was accessed $(n=21)$. When information was not available it was coded to a "missing" category. Secondly, to distinguish between the use of concepts and the use of theory, theses were coded to "theory" only when a specific theory was mentioned in the abstract. This may have resulted in some bias as researchers, anthropologists in particular, do not set out to test theories but take a more grounded approach to research with concepts/theories emerging from the fieldwork. This potential limitation is discussed more fully in the findings.

Finally the choice of search terms may have acted as a limiting factor in sourcing dissertations that indeed focus on some aspects of tourism but that do not specifically refer to "tourism" or related terms in the abstract. For instance, this may be especially relevant for anthropology and sociology theses undertaken in the context of festivals and events, so caution must be exercised when interpreting results in these contexts.

\section{RESULTS}

\section{Overview of theses}

As already noted, 292 theses drew on anthropology and 220 drew on sociology, with 36 of these being informed by both anthropology and sociology. As tourism is an interdisciplinary area of inquiry, studies informed by sociology and anthropology often connect with other disciplines, however relatively few were found to do so in the theses examined: environmental studies (10\% of the theses), history ( $8 \%$ of the theses), geography ( $8 \%$ of the theses), psychology (7\% of the theses) and urban and regional planning ( $5 \%$ of the theses).

The first tourism-focused $\mathrm{PhD}$ thesis to draw on anthropology (and geography) was completed in 1969 and the first dissertation to draw on sociology (and geography) was completed in 1978, both in the United States. In the years since these first tourism-focused theses, the number of anthropology/sociology dissertations focused on tourism has increased exponentially $\left(y=0.995 \mathrm{e}^{0.0935 \mathrm{x}}\right.$, $\mathrm{R}^{2}=0.7802$ ), particularly since 1990 (see Figure 1). This follows a trend reported for all tourismfocused theses in this period (Weiler et al., 2012). While the long-term growth trend in anthropology/sociology tourism theses has been exponential, since 2008 there has been a drop in the number of tourism theses employing sociology/anthropology. 


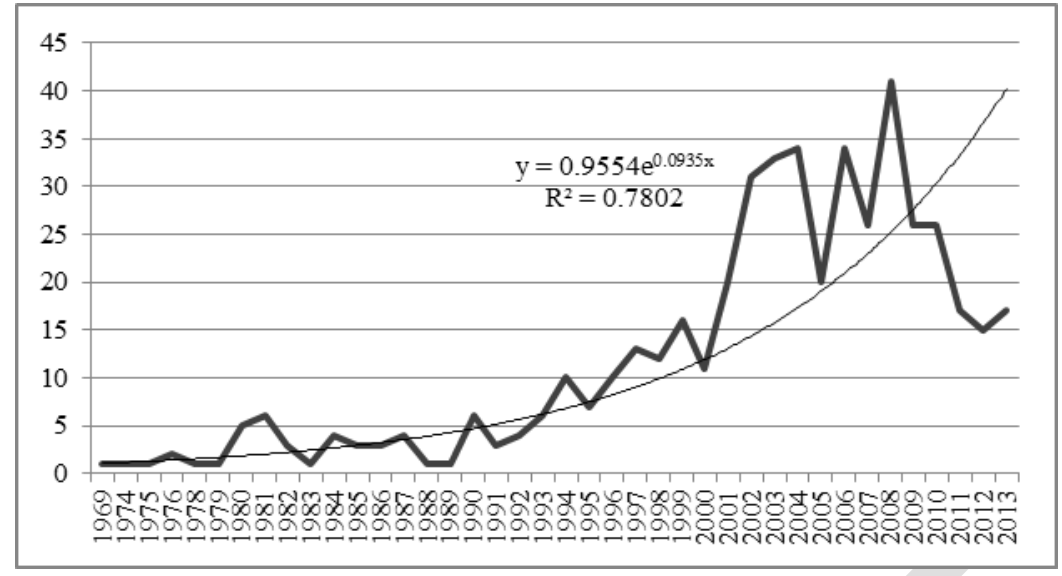

Figure 1. Number of tourism-focused anthropology/sociology theses, 1969-2013.

Nearly two-thirds of the theses informed by anthropology/sociology have been completed in the United States (63.0\%) (see Table 1) and eleven universities account for nearly a third of all sociology/anthropology tourism theses (see Table 2). Perhaps not surprisingly, most of these are American universities, however three of these eleven universities are based in Australia, one is in New Zealand and one is in Canada.

Table 1. Number of tourism doctoral theses informed by anthropology/sociology, by country.

\begin{tabular}{lrr}
\hline Country & Freq. & Percent \\
\hline USA & 300 & 63 \\
Australia & 113 & 23.7 \\
New Zealand & 36 & 7.6 \\
Canada & 27 & 5.7 \\
Total & $\mathbf{4 7 6}$ & $\mathbf{1 0 0}$ \\
\hline
\end{tabular}

Seventy-two percent (or 344) of the theses noted a study location. The most commonly researched locations were the United States (62 theses), Australia (30 theses), China (24 theses), Mexico (19 theses), New Zealand (13 theses), Thailand (12 theses) and India (10 theses). Twenty-two percent of the theses also considered a particular type of tourism or context. Of these, 32 researched cultural/heritage or ethnic tourism, 19 explored alternative/volunteer tourism, 10 theses focused on sex or romance tourism, 7 explored adventure/safari tourism and 6 focused on lifestyle travellers or backpackers. 
Table 2. Educational institutions that produce the greatest number of tourism doctoral theses informed by anthropology/sociology.

\begin{tabular}{rllr}
\hline Rank & University & Country & Freq. \\
\hline 1 & University of California & USA & 37 \\
2 & University of Queensland & Australia & 16 \\
3 & Texas A\&M University & USA & 14 \\
4 & James Cook University & Australia & 12 \\
5 & University of Otago & New Zealand & 12 \\
6 & University of Florida & USA & 11 \\
7 & University of Texas & USA & 11 \\
8 & University of Illinois & USA & 9 \\
9 & University of Waterloo & Canada & 9 \\
10 & City University of New York & USA & 8 \\
11 & Griffith University & Australia & 8 \\
& Total & & $\mathbf{1 4 7}$ \\
\hline
\end{tabular}

\section{Concepts}

Using the information provided in the abstracts, the dissertations were coded with respect to one or more concepts previously identified in the literature (Weiler et al., 2012). As shown in Table 3, about one-quarter (122) of the theses approached the study of tourism from an "impact" framework, exclusively or in combination with other important concepts such as "identity" (119 theses), "culture" (97), "representation" (51 theses), "intercultural contact" (48 theses) and "gender" (47 theses). The term "impacts" is often replaced or used in conjunction with other terms such as "change" and "transformation" particularly from the 1990s onwards. The "socio-cultural impacts of tourism" and "quality of life" were significantly more likely to be used together as concepts in theses (two-tailed Fisher's exact test, $\mathrm{p}=.029$ ), while "socio-cultural impacts" was less likely to be used with "identity" $\left(\chi^{2}(1)=16.00, p<.001\right)$ and "environmental sustainability/nature" (two-tailed Fisher's exact test, $p=$ $.046)$.

"Identity" is the second most frequently used concept employed in these studies and was often used interchangeably with "national identity" or "ethnic identity". "Identity" and "sense of place/community" were significantly more likely to be used together $\left(\chi^{2}(1)=6.43, p=.011\right)$, as opposed to "identity" and "intercultural contact" which were less likely to be used together $\left(\chi^{2}(1)=\right.$ 7.91, $\mathrm{p}=.005)$. In addition, theses that employed identity as a conceptual framework were significantly more likely to draw on "power" $\left(\chi^{2}(1)=5.52, \mathrm{p}=.019\right)$; "tourist gaze" $\left(\chi^{2}(1)=4.10, \mathrm{p}=\right.$ $.043)$; and "gender" $\left(\chi^{2}(1)=13.23, \mathrm{p}<.001\right)$. 
Table 3. Concepts most frequently employed in tourism-focused anthropology/sociology theses.

\begin{tabular}{lr}
\hline Concept & $\begin{array}{r}\text { No. of } \\
\text { Theses* }\end{array}$ \\
\hline Socio-cultural impacts of tourism & 122 \\
Identity/ethnicity & 119 \\
Culture/material culture/heritage & 97 \\
Representation/imagery & 51 \\
Globalisation/mobility & 49 \\
Intercultural contact & 48 \\
Gender & 47 \\
Cultural commodification & 35 \\
Spirituality / religion & 34 \\
Sense of place / community & 32 \\
Authenticity & 31 \\
Performance & 30 \\
Community development / well-being & 28 \\
Sexuality / romance & 17 \\
Power & 16 \\
Politics / cultural politics & 14 \\
Environmental sustainability/nature & 13 \\
Tourist gaze & 12 \\
Acculturation / multiculturalism & 10 \\
Leisure / recreation & 10 \\
Social justice / social (in)equality & 9 \\
Quality of Life & 8 \\
Consumption & 8 \\
Resilience & 6 \\
Poverty alleviation & 6 \\
Other & 6 \\
\hline
\end{tabular}

*total exceeds number of theses, as many employ multiple concepts

"Culture" and related concepts (e.g. heritage, art and craft, food) was also a frequently-used concept, employed in 97 of the theses analysed. "Culture" was significantly more likely to be used with "representation" $\left(\chi^{2}(1)=7.83, p=.005\right)$ and "identity" $\left(\chi^{2}(1)=17.13, p<.001\right)$, and less likely to be used in conjunction with "impacts" $\left(\chi^{2}(1)=19.31, p<.001\right)$ and "sexuality/romance" (two-tailed Fisher's exact test, $p=.030$ ).

\section{Theory}

As previously discussed, theses were only coded to the category "theory" when specific mention was made in the abstract. An evident limitation of this approach is the reliance on abstracts to identify theories, with a high number of theses (67\%) coded as not guided by any particular theory (theories) 
based on this method. A reading of the full thesis may well have revealed that one or more theories did indeed drive the research. Due to the small sample size, and that most theses only drew on one theory, no correlations could be tested between the theories. However, correlations have been tested with concepts, still providing a rich picture of the trends in the sociological and anthropological study of tourism at doctoral level.

Table 4 lists all theories used in three or more theses. Of those 158 theses that did use a theory, the most commonly used theory was "identity/social identity theory", used in $25 \%$ of those theses that employed theory. Thirty-eight theses (or $24 \%$ of those theses that employed theory) drew on more than one theory. Theses informed by sociology were more likely to mention theory, with $40 \%$ of the sociology theses drawing on at least one theory compared with $30 \%$ of anthropological theses.

Notably, of the 36 theses informed by both sociology and anthropology half used a theory, making these types of theses significantly $\left(\chi^{2}(2)=11.49, p=.003\right)$ more likely to employ theory than those theses informed by only one of these two disciplines.

Table 4. Theories most frequently used to inform tourism-focused anthropology/sociology theses.

\begin{tabular}{lr}
\hline Theory & $\begin{array}{r}\text { No. of } \\
\text { Theses }\end{array}$ \\
\hline Identity/Social identity theory & 39 \\
Modernity/Modernisation theory & 19 \\
Neocolonialism/Postcolonial theory & 17 \\
Development theory/Sustainable tourism development & 13 \\
Social exchange theory & 10 \\
Feminist theory & 9 \\
Political economy theory & 8 \\
Performance theory/performativity & 8 \\
Critical theory & 7 \\
Poststructuralist/postmodern theory & 6 \\
General systems theory/World system & 5 \\
Political ecology framework/Theory & 5 \\
Social/cultural Capital Theory & 4 \\
Sustainable Livelihood Approach (SLA)/ Sustainable & \\
tourism based livelihood Framework (STBLF) & 4 \\
Stakeholder theory & 4 \\
Symbolic interaction/interactionism & 35 \\
Social representation & 3 \\
A variety of theories used in only 1 or 2 theses & 3 \\
\hline
\end{tabular}

After "identity/social identity theory", the most commonly used theories were "modernity/modernisation theory", "neo-colonialism", "development theory/sustainable tourism development" and "social exchange theory". Interestingly, theses that employed the conceptual 
framework of "culture" were less likely to mention a specific theory in the abstract $\left(\chi^{2}(1)=11.77, p<\right.$ .001). This may be because most studies that explore culture are, in fact, anthropological studies which take a grounded approach to research and build theory from ethnographic fieldwork rather than test theory as is more common in sociological studies (Leite \& Swain, 2015; Hammersley \& Atkinson, 2007).

Doctoral studies that employed "identity" as a concept were significantly more likely to use theory $\left(\chi^{2}(1)=7.89, p=.005\right)$ and, not surprisingly, they employed "identity/social identity theory" (twotailed Fisher's exact test, $p<.001)$. Studies that employed the concept of "sense of place" were also more likely to use "identity/social identity theory" (two-tailed Fisher's exact test, $p=.037$ ). Finally, studies that used a "social justice" approach were significantly more likely to use "modernity/modernisation theory" (two-tailed Fisher's exact test, $p=.022$ ). An interesting conundrum which is evident in Table 4 is the large number of theories that are employed in only one or two theses. This seems to suggest a breadth of theoretical development but little refinement and testing of theory.

\section{Context}

Twenty-two percent of doctoral studies informed by sociology and anthropology researched a particular type of tourism or context. The type of tourism most often researched was "culture/heritage/ethnic tourism" (32 theses). Cultural tourism was significantly more likely to be researched with concepts such as "performance" $\left(\chi^{2}(1)=5.05, p=.025\right)$; "culture" $\left(\chi^{2}(1)=11.55, p=\right.$ $.001)$; "representation" $\left(\chi^{2}(1)=7.32, p=.007\right)$; "identity" $\left(\chi^{2}(1)=4.47, p=.035\right)$; and "authenticity" $\left(\chi^{2}(1)=19.26, p<.001\right)$; whereas it was less likely to be researched with "impacts" (two-tailed Fisher's exact test, $p=.034)$.

The second most frequently researched context "alternative/volunteer tourism" (19 theses) was more likely to be approached from a "social justice" perspective $\left(\chi^{2}(1)=25.37, p<.001\right)$; "community development" $\left(\chi^{2}(1)=29.90, p<.001\right)$; "quality of life" (two-tailed Fisher's exact test, $\mathrm{p}=.015$ ); and "political ecology" perspective (two-tailed Fisher's exact test, $p=.010$ ). "Sex/romance" tourism was significantly more likely to be studied with concepts such as "sexuality/romance" (two-tailed Fisher's exact test, $p<.001)$, "gender" $\left(\chi^{2}(1)=29.90, p<.001\right)$, and theories such as "political economy" (two-tailed Fisher's exact test, $p=.010$ ).

\section{Methods employed}

Dissertations in the database were also coded according to the methodological approach and methods employed. Figure 2 shows a prevalence of qualitative and mixed methods approaches in the 
anthropological and sociological study of tourism. Qualitative and mixed methods studies have also grown exponentially over the years notwithstanding a noticeable drop since 2008. Ethnography was the main method employed (170 theses), followed by interviews (101 theses), observation ( 87 theses), surveys ( 58 theses) and case studies (55 theses). Other methods which were used often included visual material analysis (including media, web, textual, photo and film), historical and archival analysis, content and thematic analysis and narrative analysis. Among those that employed interviews, face-toface interviews were used in the majority ( 28 theses), followed by informal conversations ( 8 theses) and life history interviews ( 7 theses). Surveys were mainly field/on-site surveys (18 theses) or web/email surveys (5 theses). As previously discussed, due to the variation in length and quality of the abstracts information was often missing. This was particularly so for theses completed more than a decade ago and which could not be accessed online. When information about the methods was missing, it was coded to a "missing" category (41 theses).

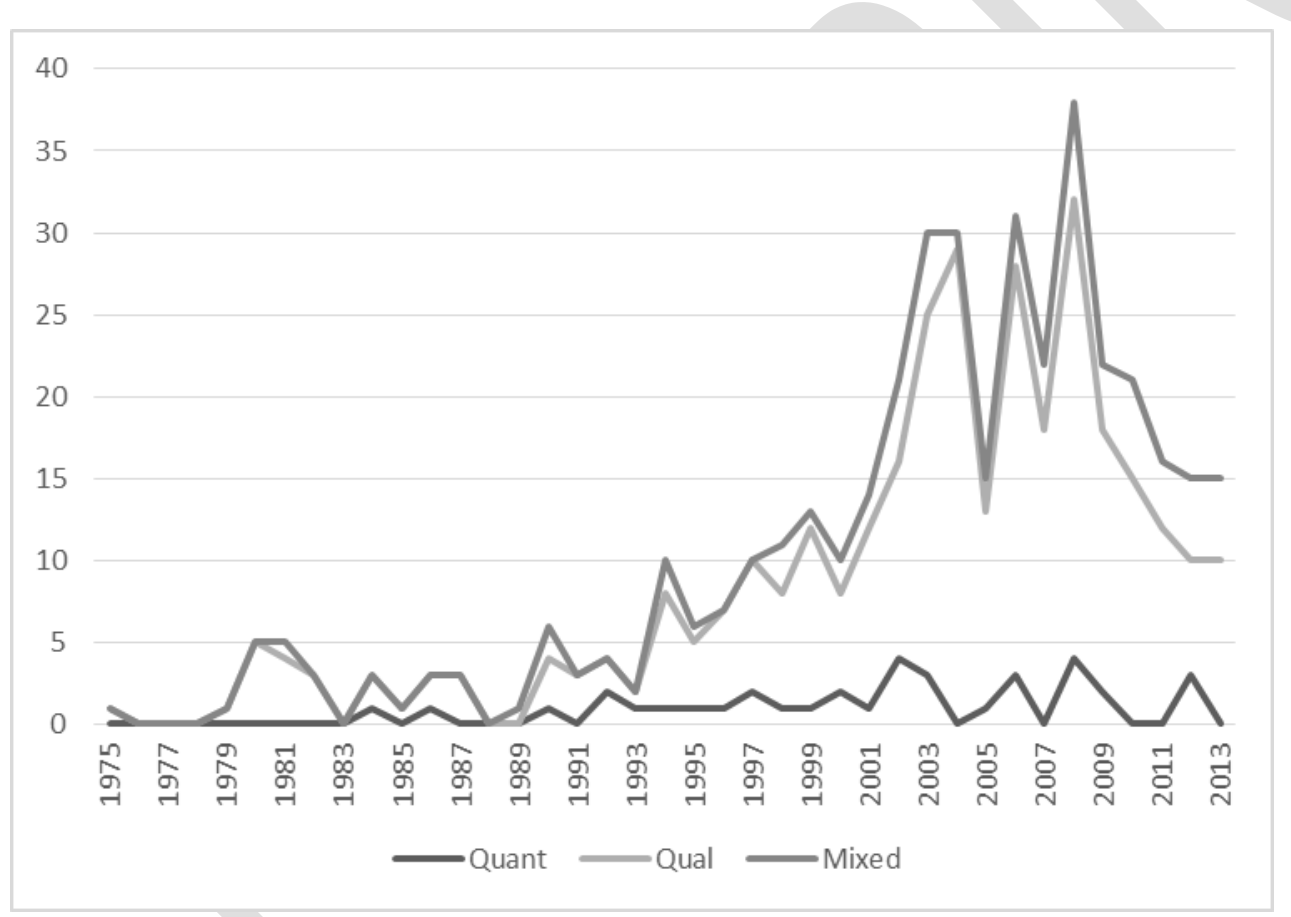

Figure 2. Methodological approach of tourism-focused anthropology/sociology theses, 1975-2013 Theses prior to 1975 did not state methods in their abstract. 


\section{DISCUSSION AND CONCLUSION}

The aim of this paper was to explore the theories, concepts and methods employed in tourism doctoral research informed by the disciplines of anthropology and sociology. To achieve this objective, the paper examined $476 \mathrm{PhD}$ dissertations completed in the United States, Canada, Australia and New Zealand that drew on the disciplines of anthropology and sociology. Since the contribution of sociology and anthropology to doctoral research has grown exponentially since 1969 - as opposed to other disciplines such as economics which have declined considerably (Moyle, Weiler and McLennan, 2012) - it is important to understand how the two disciplines have contributed to the study of tourism. By analysing the concepts, theories and methods employed in the theses it is possible to identify the major theoretical and methodological contributions and trends in the sociological and anthropological study of tourism. In addition, exploring the trends that have occurred over time in tourism anthropology and sociology reveal the changes occurring and anticipate where these areas of tourism research might evolve in the future. This provides future $\mathrm{PhD}$ candidates and emerging and established scholars with interests in anthropology and sociology with more directed information about influential gaps for conceptual and theoretical advancement.

The ten concepts most frequently employed include: "impacts" (122 theses), "identity" (119 theses), "culture" (97 theses), "representation" (51 theses), "globalisation/mobility" (49 theses), "intercultural contact" (48 theses), "gender" (47 theses), "cultural commodification" (35 theses), "spirituality/religion" (34 theses), "sense of place/community" (32 theses) (see Table 3). In the last two decades, there has also been a rise in doctoral research employing concepts such as "performance", "community development/well-being", "sexuality/romance" and "power". The ten theories most often used to inform the research include: "identity/social identity" (39 theses), "modernity/modernisation theory" (19 theses), "postcolonial theory" (17 theses), "development theory/sustainable tourism development" (13 theses), "social exchange theory" (10 theses), "feminist theory" (9 theses), "political economy theory" ( 8 theses), "performance theory" ( 8 theses), "critical theory" (7 theses), "poststructuralist/postmodern theory" (6 theses). Although still low in number, studies in the last decade are moving towards "social justice", "activism" and "embodiment" conceptual frameworks. There has also been a rise in studies on alternative tourism, ecotourism and volunteer tourism from a community development and empowerment approach.

With the propagation of a critical scholarship in tourism studies (Ateljevic, Pritchard and Morgan, 2007; Higgins-Desbiolles and Whyte, 2013; Pritchard et al., 2011), Tribe and Liburd (2016) argue that a "value-based" approach to the study of tourism is on the rise. According to Cohen and Cohen (2012), critical approaches to the sociology of tourism have created new research avenues including social justice, environmental sustainability (including climate change), natural disasters and terrorism (including dark tourism), and embodiment and affect. Likewise, Leite and Graburn (2009: 54) explore 
some of the emerging research directions in the anthropology of tourism which "could be considered postmodern or even post-disciplinary". These include medical tourism; social (in)equality, tourism and power (including eco-tourism and community empowerment); tourism and activism (voluntourism); and tourism and kinship (including roots or genealogical tourism). Unfortunately, however, from the abstracts alone it was not always possible to glean whether the dissertations were informed by critical theory. This may have influenced the low number of theses in this category (see Table 4). Nevertheless, findings in the present study suggest that the developments in the study of tourism at doctoral level closely correspond with these broader disciplinary trends in sociology and anthropology.

An important example of this is the "impact model" of tourism widespread in tourism-focused doctoral research informed by sociology and/or anthropology between the 1970s and 1990s. Dissertations completed in the last two decades have moved away from the impact model of tourism to focus more on the active and creative way host populations adapt to tourism (Canosa, 2016; Picard, 1995). Impacts are thus replaced by the adaptations and transformations of local identities, cultures and customs to tourism and the global economy (Leite and Graburn, 2009; Hollinshead, 2009).

The second most frequently employed concept in this study - and first most commonly employed theory - was, in fact, identity and identity theory. Findings in this study suggest that the adoption of "identity" as a theoretical framework is more prominent in the last two decades of doctoral-based tourism research in sociology and anthropology. This reflects a broader theoretical development in the sociology and anthropology of tourism away from the notion of tourism as an exogenous force impacting upon passive host communities towards conceptualising tourism as an agent of social change and catalyst for the transformation and valorisation of identities and cultures (Canosa, Moyle and Wray, 2016; Hollinshead, 2009; Lanfant et al., 1995; Leite and Graburn, 2009; Picard, 1995; Stronza, 2001).

This approach is often coupled with critical, poststructuralist, postmodern and/or feminist theoretical approaches. It is thus not surprising that "identity" was less likely to be employed with "impacts" and more likely to be used with "sense of place", "power" and "gender". Discourse surrounding tourism has over the years changed; tourism is now recognised for the important role it has in shaping, creating and perpetuating national and ethnic identities (Hollinshead, Ateljevic and Ali, 2009; Lanfant et al., 1995; Scott and Selwyn, 2010). The politics of identity are now studied in a multiplicity of contexts in the sociology and anthropology of tourism at doctoral level.

Another important concept employed in this study was "culture", including material culture (art, craft and food) and heritage. This concept was used in 97 of the theses analysed and was more likely to be explored in the context of "cultural/heritage/ethnic tourism". "Representation" - including tourist imaginaries and the production and consumption of images (Gravari-Barbas and Graburn, 2012; 
Salazar, 2012) - also featured prominently in tourism doctoral research (51 theses) and seems to have supplanted early interest in "cultural commodification". Leite and Graburn (2009: 47) also argue that anthropologists' initial interest in the commodification of culture in host communities has now been replaced by an interest in "how place is created anew in each tourist encounter, based on the imaginings, desires, and interests of the individual visitor and mediated by tour guides, guidebooks, and other markers".

This study also reveals a growing focus on "globalisation/ mobility" (49 theses), and the decline of concepts such as the "tourist gaze" (12 theses). Cohen and Cohen (2012: 2180) argue that the move away from the concept of the tourist gaze (Urry, 1990) - which was prevalent in the late 1990s and early $21^{\text {st }}$ century - towards the "mobility paradigm" is the "most encompassing theoretical development of the last decade" in the sociology of tourism. Moving away from the concept of the tourist gaze, Urry (2000: 186) argued for a "novel agenda for sociology" based on the notion of "social as mobility" rather than "social as society". The emerging mobility paradigm calls for a greater focus and attention to "the diverse mobilities of peoples, objects, images, information and wastes; and the complex interdependencies between, and social consequences of, these diverse mobilities" (Urry, 2010: 348). The proliferation of anthropological studies on identity and the rise in migration and diaspora ethnographies in the 1990s bear witness to this growing interest in mobility and identity (Chamberlain, 1995).

Early anthropological and sociological studies concerned with "authenticity" have also recently declined, as has interest in the "spiritual" dimensions of tourism and pilgrimage tourism. Findings in this study suggest there has been an increasing interest in gender, sexuality and embodiment (see also Frohlick, 2008; Jacobs, 2009; Johnston, 2001; Jordan and Aitchison, 2008; Pritchard and Morgan, 2006; Simoni, 2014; Small, 2016; Veijola and Jokinen, 1994; Weichselbaumer, 2012). The methodological limitation of sourcing dissertations that specifically mentioned "tourism" and related terms in the abstract, may have, however, silenced the theoretical contributions of queer and feminist scholars, as well as, those who are theorizing tourism utilizing affect theory and non-representational theories. "Tourism" may not appear in the abstracts of these studies, yet their work provides potentially incisive empirical and theoretical accounts of tourism (see, for example, Cooke, 2009; Lozanski, 2007).

In addition, in the last two decades tourism doctoral research in sociology and anthropology has shifted its focus to tourism and tourists per se, as opposed to earlier studies which were most often ethnographic accounts of particular communities and cultures where tourism was only considered as an agent of change (Harrison, 2001, 2003). While the modes of knowledge production have been consistant in the sociology/anthropology of tourism (i.e. ethnography being the dominant methodological approach), these have increasingly adapted to capture the mobility of people and 
places. This is reflected in the rise in visual and web-based analysis (49 theses) and the adoption of "multi-sited" ethnographies (Kurotani, 2004; Marcus, 1995).

In conclusion, this study demonstrates how analysing tourism doctoral research provides a rich and nuanced picture of the theoretical, conceptual and methodological contribution of sociology and anthropology to tourism studies. The results show how the historical evolution and trends in the approaches taken in doctoral research on tourism mirror the developments in these two disciplines and perhaps even drive such progress. Anthropology and sociology have followed similar historical evolutions and isolating their contribution to tourism research is not easy and probably not particularly useful; hence the decision to explore both sociology and anthropology to gauge and map the contribution that these two disciplines have had on tourism doctoral research.

Although Weiler et al. (2012: 1442) argue that most individual theses are "single discipline-based" rather than multidisciplinary, the fusion of sociological and anthropological theory in the study of tourism among the dissertations examined in the present study points to a crossing of disciplinary boundaries. Nevertheless, beyond sociology and anthropology relatively few dissertations also connected to other key disciplines such as environmental studies, history, geography and psychology, and even fewer to disciplines such as business, economics, management and marketing. This would suggest there is an opportunity to increase the multi-disciplinary nature of tourism doctoral research that draws on sociology and anthropology.

Two important questions still remain unanswered. Firstly, why are some institutions producing high numbers of doctoral theses in sociology and anthropology? Are staff with academic training in sociology and anthropology at these institutions driving the trends observed in this study? Of course, determining the qualifications and expertise of supervisors is not always straightforward. Further research might explore if this is the case or if a more troubling scenario is unfolding whereby institutions producing sociologically and anthropologically informed theses are not actually being supervised by sociologically or anthropologically trained supervisors.

Secondly, there seems to be a dominance of a small number of theoretical 'voices' whose contribution has been overly relied upon for theoretical frameworks thus stifling or "petrifying" innovation (Franklin \& Crang, 2001: 6). If we consider the growth of anthropological and sociological doctoral research focused on tourism, it is surprising to note that the scholarship of only a small number of these voices have found their way in mainstream tourism studies. By way of comparison, a greater number of scholars in other disciplines such as geography (Che, 2017) have been prominent in publishing in and editing tourism journals, resulting in greater cross-fertilisation and theoretical breadth from which doctoral researchers can build (Moyle et al, 2013). 


\section{Funding}

The author(s) received no financial support for the research, authorship and/or publication of this article

\section{REFERENCES}

Adams, G. B. and J. D. White. (1994) 'Dissertation Research in Public Administration and Cognate Fields: An Assessment of Methods and Quality', Public Administration Review 565-76.

Adams, K. M. (2004) 'The Genesis of Touristic Imagery: Politics and Poetics in the Creation of a Remote Indonesian Island Destination', Tourist Studies: An International Journal 4(2): 115-35.

Afifi, G. M. H. (2009) 'Tourism as the Subject of Doctoral Theses in Egypt, 1975-2008', Anatolia 20(2): 387-400.

Afifi, G. M. H. (2013) 'A Survey of Doctoral Theses Accepted by Universities in the United Kingdom and Ireland for Studies Related to Tourism, 2000-2009', Journal of Hospitality \& Tourism Education 25(1): 29-39.

Appadurai, A. (1988) The Social Life of Things: Commodities in Cultural Perspective. Cambridge: Cambridge University Press.

Appadurai, A. (1998) Modernity at Large: Cultural Dimensions of Globalization. Minneapolis, MN: University of Minnesota Press.

Ateljevic, I., A. Pritchard and N. Morgan. (2007) The Critical Turn in Tourism Studies: Innovative Methodologies. Oxford: Elsevier.Research

Bandyopadhyay, R. (2011) 'A Photo Ethnography of Tourism as Neo-Colonialism', Annals of Tourism Research 38(2): 714-18.

Boissevain, J. (1977) 'Tourism and development in Malta', Development and Change, 8: 523-538.

Botterill, D., C. Haven and T. Gale. (2002) 'A survey of Doctoral Theses Accepted by Universities in the UK and Ireland for Studies Related to Tourism, 1990-1999', Tourist Studies: An International Journal 2(3): 283-311.

Bruner, E. M. (1991) 'Transformation of Self in Tourism', Annals of Tourism Research 18(2): 23850.

Bruner, E. M. (1996) 'Tourism in Ghana: The Representation of Slavery and the Return of the Black Diaspora', American Anthropologist 98(2): 290-304.

Burns, G. L. (2004) 'Anthropology and Tourism: Past Contributions and Future Theoretical Challenges', Anthropological Forum 14(1): 5-22.

Büscher, M. and J. Urry. (2009) 'Mobile Methods and the Empirical', European Journal of Social Theory 12(1): 99-116.

Canosa, A. (2014) 'The Role of Travel and Mobility in Processes of Identity Formation Among the Positanesi', Tourist Studies: An International Journal 14(2): 182-202.

Canosa, A. (2016) 'Voices from the Margin: Youth, Identity and Belonging in a Tourist Destination', Doctoral Dissertation, Southern Cross University, Lismore, NSW, Australia.

Canosa, A., A. Graham and E. Wilson. (2017) 'Growing Up in a Tourist Destination: Negotiating Space, Identity and Belonging', Children's Geographies. Epub ahead of print 31 May 2017. DOI: 10.1080/14733285.2017.1334115.

Canosa, A., B. Moyle and M. Wray. (2016) 'Can Anybody Hear Me? A Critical Analysis of Young Residents' Voices in Tourism Studies', Tourism Analysis: An Interdiciplinary Journal 21(2): 32537.

Canosa, A., E. Wilson and A. Graham. (2017) 'Empowering Young People Through Participatory Film: A Postmethodological Approach', Current Issues in Tourism 20(8): 894-907.

Carr, N. and S. Hayes. (2017) 'An Analysis of Trends in Ph.D. Research in Tourism', Tourism Recreation Research 42: 32-44.

Chamberlain, M. (1995) 'Family narratives and migration dynamics: Barbadians to Britain', Immigrants \& Minorities, 14(2): 153-169.

Che, D. (2017) 'Tourism Geography', in B. Warf (ed.) Oxford Bibliographies in Geography. New York: Oxford University Press.

Cohen, E. (1972) 'Toward a Sociology of International Tourism', Social research 39(1): 164-82.

Cohen, E. (1979) 'Rethinking the Sociology of Tourism', Annals of tourism research 6(1): 18-35.

Cohen, E. (2008) Youth Tourism to Israel: Educational Experiences of the Diaspora. Buffalo, NY: Channel View Publications.

Cohen, E. and S. A. Cohen. (2012) 'Current Sociological Theories and Issues in Tourism', Annals of Tourism Research 39(4): 2177-202.

Cooke, L. (2009) 'North to Yukon: (Beyond) the Frontier in Canadian National-Cultural Imaginaries', Doctoral Dissertation, Department of Anthropology, York University, Toronto, ON, Canada. 
Crick, M. (1989) 'Representations of International Tourism in the Social Sciences: Sun, Sex, Sights, Savings, and Servility', Annual Review of Anthropology 18: 307-44.

Dann, G. M. S. (2005) 'The Theoretical State of the Art in the Sociology and Anthropology of Tourism', Special issue from the Biennial Conference of the International Academy for the Study of Tourism 10(1): 3-15.

De Kadt, E. (1979) Tourism: Passport to development? New York: Oxford University Press.

Desforges, L. (2000) 'Travelling the world: Identity and travel biography', Annals of Tourism Research, 27(4): 926-945.

Di Giovine M (2011) 'Tourism Research as "Global Ethnography," Anthropologies: A Collaborative online project'. Available at: http://www.anthropologiesproject.org/2011/04/tourism-research-asglobal-ethnography.html (accessed 15 September 2016).

Duval, D. T. (2003) 'When Hosts Become Guests: Return Visits and Diasporic Identities in a Commonwealth Eastern Caribbean Community', Current Issues in Tourism 6(4): 267-308.

Easterling, D. S. (2004) 'The Residents' Perspective in Tourism Research', Journal of Travel \& Tourism Marketing 17(4): 45-62.

Edensor, T. (2001) 'Performing Tourism, Staging Tourism: (Re)Producing Tourist Space and Practice', Tourist Studies: An International Journal 1(1): 59-81.

Errington, F. and D. Gewertz. (1989) 'Tourism and Anthropology in a Post-Modern World', Oceania 60: $37-54$.

Franklin, A. and M. Crang. (2001) 'The Trouble with Tourism and Travel Theory?' Tourist Studies: An International Journal 1: 5-22.

Frohlick, S. (2008) 'Negotiating the Public Secrecy of Sex in a Transnational Tourist Town in Caribbean Costa Rica', Tourist Studies: An International Journal 8(1): 19-39.

Frohlick, S. and L. Johnston. (2011) 'Naturalizing Bodies and Places: Tourism Media Campaigns and Heterosexualities in Costa Rica and New Zealand', Annals of Tourism Research 38(3): 1090-109.

Graburn, N. H. H. (1977) 'Tourism: The sacred journey', pp. 21-36 in V. L. Smith (ed.) Hosts and guests: The anthropology of tourism. Philadelphia, PA: University of Pennsylvania Press.

Graburn, N. H. H. (1983) 'The Anthropology of Tourism', Annals of Tourism Research 10(1): 9-33.

Gravari-Barbas, M. and N. H. H. Graburn. (2012) 'Editorial: Tourist Imaginaries', International Interdisciplinary Review of Tourism 1(1): 1-5.

Hall, C. M. (1991) 'Tourism as the subject of post-graduate dissertations in Australia', Annals of Tourism Research, 18(3): 520-523.

Hall, S. (1996) 'Introduction: Who Needs "Identity", pp. 1-17 in S. Hall and P. Du Gay (eds) Questions of cultural identity. London: SAGE.

Hall, C. M. and T. Pedrazzini. (1989) 'Australian higher degree theses in tourism, recreation and related subjects', Occasional paper No. 2. Lismore, Northern Rivers: Australian Institute of Tourism Industry Management, University of New England.

Hammersley, M. and P. Atkinson. (2007) Ethnography: Principles in practice. London: Taylor \& Francis.

Hannam, K., M. Sheller and J. Urry. (2006) 'Editorial: Mobilities, Immobilities and Moorings', Mobilities 1(1): 1-22.

Harrison, J. (2001) 'Thinking about Tourists', Journal of Sociology 16: 159-72.

Harrison, J. (2003) Being a Tourist: Finding Meaning in Pleasure Travel. Vancouver, BC, Canada: UBC Press.

Higgins-Desbiolles, F. and K. P. Whyte. (2013) 'No high hopes for hopeful tourism: A critical comment', Annals of Tourism Research, 40: 428-433.

Hollinshead, K. (2009) 'The "worldmaking" prodigy of tourism: The reach and power of tourism in the dynamics of change and transformation', Tourism Analysis: An Interdisciplinary Journal, 14(1): 139-152.

Hollinshead, K., I. Ateljevic and N. Ali. (2009) 'Worldmaking agency-worldmaking authority: The sovereign constitutive role of tourism', Tourism Geographies, 11(4): 427-443.

Huang, S. S. (2011) 'Tourism as the subject of China's doctoral dissertations', Annals of Tourism Research, 38(1): 316-319.

Jacobs, J. (2009) 'Have sex will travel: Romantic 'sex tourism'and women negotiating modernity in the Sinai', Gender, Place and Culture, 16(1): 43-61.

Jafari, J. (2003) 'Research and Scholarship: The Basis of Tourism Education', Journal of Tourism Studies 14(1): 6-16.

Jafari, J. and D. Aaser. (1988) 'Tourism as the Subject of Doctoral Dissertations', Annals of Tourism Research 15(3): 407-29.

Jafari, J., and J. R. B. Ritchie. (1981) 'Towards a framework for tourism education: Problems and prospect', Annals of Tourism Research, 8(1): 13-34.

Johnston, L. (2001) '(Other) bodies and tourism studies', Annals of Tourism Research, 28(1): 180-201. 
Jordan, F. and C. Aitchison. (2008) 'Tourism and the sexualisation of the gaze: Solo female tourists' experiences of gendered power, surveillance and embodiment', Leisure Studies, 27(3): 329-349.

Kearney, M. (1995) 'The Local and the Global: The Anthropology of Globalization and Transnationalism', Annual Review of Anthropology 24: 547-65.

Kurotani, S. (2004) 'Multi-sited transnational ethnography and the shifting construction of fieldwork', pp. 201-215 in L. Hume \& J. Mulcock (eds.), Anthropologists in the field: Cases in participant observation. New York: Columbia University Press.

Laing, J. H. and B. Weiler. (2008) 'Postgraduate tourism research in Australia: A trend analysis 19692005 ', pp. 602-614 in S. Richardson, L. Fredline, A. Patiar and M. Ternel (eds.), CAUTHE 2008: Tourism and hospitality research, training and practice; "where the 'bloody hell' are we?" Gold Coast, QLD: Griffith University.

Lanfant, M.-F., J. B. Allcock and E. M. Bruner. (eds.) (1995) International tourism: Identity and change. London: Sage

Leiper, N. (1981) 'Towards a Cohesive Curriculum Tourism: The Case for a Distinct Discipline', Annals of Tourism Research 8(1): 69-84.

Leite, N. (2005) 'Travels to an Ancestral Past: On Diasporic Tourism, Embodied Memory, and Identity', Anthropologicas 9: 273-302.

Leite, N. (2014) 'Afterword: Locating Imaginaries in the Anthropology of Tourism', pp. 365-91 in N. B Salazar and N. Graburn (eds) Tourism Imaginaries: Anthropological Approaches. Oxford: Berghahn.

Leite, N. and M. B. Swain. (2015) 'Anthropology of Tourism', in J. Jafari and H. Xiao (eds) Encyclopedia of Tourism, 2nd edn. London: Springer. Available at: https://books.google.co.in/books?id=2a-

LKXPUmD8C \&printsec=frontcover\&source $=$ gbs_ge_summary_r\&cad $=0 \# v=$ onepage $\& q=$ Anthrop ology\%20of\%20Tourism\%E2\%80\%99\&f=false

Leite, N. and N. Graburn. (2009) 'Anthropological Interventions in Tourism Studies', pp. 35-64 in T. Jamal and M. Robinson (eds) The SAGE handbook of tourism studies. Los Angeles, CA: SAGE.

Lett, J. (1989) 'Epilogue', pp. 275-79 in V. L. Smith (ed.) Hosts and guest: The anthropology of tourism, 2nd edn. Philadelphia, PA: University of Pennsylvania Press.

Lozanski, K. (2007) 'Colonial Legacies and Independent Travel to India: Questions of Identity in a Context of Global Inequality', Doctoral Dissertation, Department of Sociology, University of Alberta. Edmonton, AB, Canada.

McCabe, S. and E. H. Stokoe. (2004) 'Place and Identity in Tourists' Accounts', Annals of Tourism Research 31(3): 601-22.

MacCannell, D. (1976) The Tourist: A New Theory of the Leisure Class, New York: Schocken Books.

McGibbon, J. (1999) The Business of Alpine Tourism in a Globalising World: An Anthropological Study of International Ski Tourism in the Village of St. Anton am Arlberg in the Tirolean Alps. Rosenheim: Vetterling Druck.

Marcus, G. E. (1995) 'Ethnography in/of the world system: The emergence of multi-sited ethnography', Annual Review of Anthropology, 24(1): 95-117.

Marcus, G. E. and M. M. Fischer. (1986) Anthropology as Cultural Critique: An Experimental Moment in the Human Sciences. London: The University of Chicago Press.

Meethan, K. (2001) Tourism in global society: Place, culture, and consumption. Basingstoke: Palgrave Macmillan.

Meyer-Arendt, K. J. and C. Justice. (2002) 'Tourism as the Subject of North American Doctoral Dissertations, 1987-2000', Annals of Tourism Research 29(4): 1171-74.

Mkono, M. (2012) 'Netnographic tourist research: The internet as a virtual fieldwork site', Tourism Analysis, 17(4): 553-555.

Morgan, N. and A. Pritchard. (2005) 'On Souvenirs and Metonymy: Narratives of Memory, Metaphor and Materiality', Tourist Studies: An International Journal 5(1): 29-53.

Moyle, B. D., B. Weiler and C. McLennan. (2013) 'The Disciplinary Influence of Economics and Geography in Tourism Doctoral Research', pp 79-94 in M. Kozak and N. Kozak (eds) Tourism Research: An Interdisciplinary Perspective. Cambridge: Cambridge Scholars Publishing.

Nash, D. (1977) 'Tourism as a form of Imperialism', pp. 37-54 in V. L. Smith (ed.) Hosts and Guests: The Anthropology of Tourism. Philadelphia, PA: University of Pennsylvania Press.

Nash, D. (2007) The study of tourism: Anthropological and sociological beginnings. Oxford: Elsevier.

Nash, D. and V. L. Smith. (1991) 'Anthropology and Tourism', Annals of Tourism Research 18(1): $12-25$.

Noy, C. (2004) 'This Trip Really Changed Me: Backpackers' Narratives of Self-Change', Annals of Tourism Research 31(1): 78-102.

Nuñez, T. A. (1963) 'Tourism, Tradition and Acculturation: Weekendismo in a Mexican Village', Ethnology 2(3): 347-52. 
Olwig, K. F. (1997) 'Cultural Sites: Sustaining a Home in a Deterritorialised World', pp. 17-38 in K. F Olwig and K. Hastrup (eds) Siting culture The shifting anthropological object. London: Routledge.

Picard, M. (1995) 'Cultural Heritage and Tourist Capital: Cultural Tourism in Bali', pp. 44-66 in M. F. Lanfant, J. B. Allcock and E. M. Bruner (eds) International Tourism: Identity and Change. London: SAGE.

Poole, P. (1994) 'Socialisation, Enculturation and the Development of Personal Identity', pp. 831-60 in T. Ingold (ed.) Companion encyclopaedia of anthropology. London: Routledge.

Pritchard, A. and N. Morgan. (2006) 'Hotel Babylon? Exploring Hotels as Liminal Sites of Transition and Transgression', Tourism Management 27(5): 762-72.

Pritchard, A., N. Morgan and I. Ateljevic. (2011) 'Hopeful Tourism: A New Transformative Perspective', Annals of Tourism Research 38(3): 941-63.

Rakić, T. and D. Chambers. (2010) 'Innovative Techniques in Tourism Research: An Exploration of Visual Methods and Academic Filmmaking', International Journal of Tourism Research 12(4): $379-89$.

Rapport, N. and A. Dawson. (1998) 'Home and Movement: A Polemic', pp. 19-38 in N. Rapport and A. Dawson (eds) Migrants of identity: Perceptions of home in a world of movement. Oxford: Berg.

Ren, C. (2011) 'Non-Human Agency, Radical Ontology and Tourism Realities', Annals of Tourism Research 38(3): 858-81.

Ren, C., A. Pritchard and N. Morgan. (2010) 'Constructing Tourism Research: A Critical Inquiry', Annals of Tourism Research 37(4): 885-904.

Rydzik, A., A. Pritchard, N. Morgan, et al. (2013) 'The Potential of Arts-Based Transformative Research', Annals of Tourism Research 40: 283-305.

Salazar, N. B. (2010) 'Towards an Anthropology of Cultural Mobilities', Crossings: Journal of Migration and Culture 1(1): 53-68.

Salazar, N. B. (2012) 'Tourism imaginaries: A conceptual approach', Annals of Tourism Research 39(2): 863-82.

Sampaio, S., V. Simoni and C. Isnart. (2014) 'Tourism and Transformation: Negotiating Metaphors, Experiencing Change', Journal of Tourism and Cultural Change 12(2): 93-101.

Scarles, C. (2010) 'Where Words Fail, Visuals Ignite: Opportunities for Visual Autoethnography in Tourism Research', Annals of Tourism Research 37(4): 905-26.

Schwartz, T. (1995) 'Cultural Totemism: Ethnic Identity, Primitive and Modern', pp. 48-72 in L. Romanucci-Ross and G. A. De Vos (eds) Ethnic Identity: Creation, Conflict, and Accommodation. Walnut Creek, CA: AltaMira Press.

Scott, J. and T. Selwyn. (2010) 'Introduction: Thinking Through Tourism: Framing the volume', pp. 1-25 in J. Scott and T. Selwyn (eds) Thinking through tourism. Oxford: Berg.

Simoni, V. (2014) 'Coping with ambiguous relationships: Sex, tourism, and transformation in Cuba', Journal of Tourism and Cultural Change, 12(2): 166-183.

Small, J. (2016) 'Holiday Bodies: Young Women and their Appearance', Annals of Tourism Research 58: $18-32$.

Smith, V. L. (1977a) 'Eskimo Tourism: Micro-Models and Marginal Men', pp. 55-82 in V. L. Smith (ed.) Hosts and Guests: The Anthropology of Tourism, 1st edn. Philadelphia, PA: University of Pennsylvania Press.

Smith V. L. (ed.) (1977b) Hosts and Guests: The Anthropology of Tourism, 1st edn. Philadelphia, PA: University of Pennsylvania Press.

Spear, H. J. (2007) 'Nursing theory and knowledge development: A descriptive review of doctoral dissertations, 2000-2004', Advances in Nursing Science, 30(1): E1-E14.

Stronza, A. (2001) 'Anthropology of Tourism: Forging New ground for ecotourism and other alternatives', Annual Review of Anthropology 30: 261-83.

Swain, M. B. (1995) 'Gender in Tourism', Annals of Tourism Research 22(2): 247-66.

Tonghui, L., Y. Caihua, W. Wei, Y. Qinjian and H. Zhiping. (2016) 'Doctoral dissertations on tourism in China: A co-word analysis', Knowledge Organization, 43(6): 440-461.

Tribe, J. (2010) 'Tribes, Territories and Networks in the Tourism Academy', Annals of Tourism Research 37(1): 7-33.

Tribe, J. and J. J. Liburd. (2016) 'The Tourism Knowledge System', Annals of Tourism Research 57: 44-61.

Tribe, J., H. Xiao and D. Chambers. (2012) 'The Reflexive Journal: Inside the Black Box', Annals of Tourism Research 39(1): 7-35.

Turner, L. and J. Ash. (1975) The Golden Hordes: International Tourism and the Pleasure Periphery. London: Constable.

Turner, V. (1969) The Ritual Process. Chicago, IL: Aldine.

Urry, J. (1990) The tourist gaze: Leisure and travel in contemporary society. London: Sage.

Urry, J. (2000) Sociology Beyond Societies. London: SAGE. 
Urry, J. (2010) 'Mobile Sociology', The British Journal of Sociology 61: 347-66.

Van Gennep A (1960) The Rights of Passage. London: Routledge.

Veijola, S. and E. Jokinen. (1994) 'The body in tourism', Theory, Culture \& Society, 11(3): 125-151.

Webster, C. and S. Ivanov. (2014) 'Transforming Competitiveness into Economic Benefits: Does Tourism Stimulate Economic Growth in More Competitive Destinations?', Tourism Management 40: $137-40$.

Weichselbaumer, D. (2012) 'Sex, Romance and the Carnivalesque Between Female Tourists and Caribbean Men', Tourism Management 33(5): 1220-29.

Weiler, B., B. D. Moyle and C. McLennan. (2012) 'Disciplines that Influence Tourism Doctoral Research: The United States, Canada, Australia and New Zealand', Annals of Tourism Research 39(3): 1425-45.

Young, R. (1977) 'The Structural Context of the Caribbean Tourist Industry: A Comparative Study', Journal of Rural Cooperation 5: 657-72.

\section{Author biographies}

Antonia Canosa is an early career researcher with the Centre for Children and Young People, Southern Cross University, NSW Australia. Antonia's research interests include the anthropology and sociology of tourism, tourism doctoral research, childhood studies, and participatory and visual methodologies in tourism research with children and young people.

Brent Moyle is a Mid-Career Advance Queensland Research Fellow with the Department of Science Information Technology and Innovation, Queensland Australia. Dr Moyle is also a Senior Research Fellow in the Griffith Institute for Tourism at Griffith University, Australia. Dr Moyle's research interests include tourism sites of natural, cultural and historical significance, innovative methods in tourism research, sports tourism and tourism doctoral research.

Char-lee Moyle (nee McLennan) is a Research Fellow in the Australian Centre for Entrepreneurship (ACE) Research at the Queensland University of Technology. Char-lee's research is focused in three main streams: 1) regional economic and tourism development, transformation and innovation; 2) strategic policy and planning; and 3) the adoption of sustainability.

Betty Weiler, $\mathrm{PhD}$, is a professor in the School of Business and Tourism at Southern Cross University. Her research interests include nature based and heritage tourism, visitor behaviour, persuasive communication, tour guiding and tourism postgraduate research. 